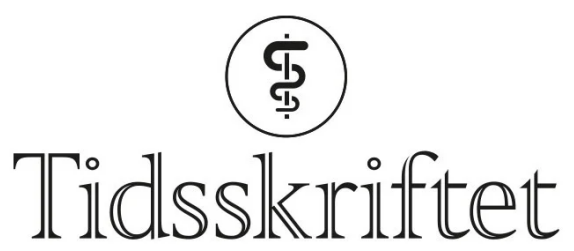

DEN NORSKE LEGEFORENING

\title{
Sverre Eika
}

MINNEORD

STIG ASPLIN

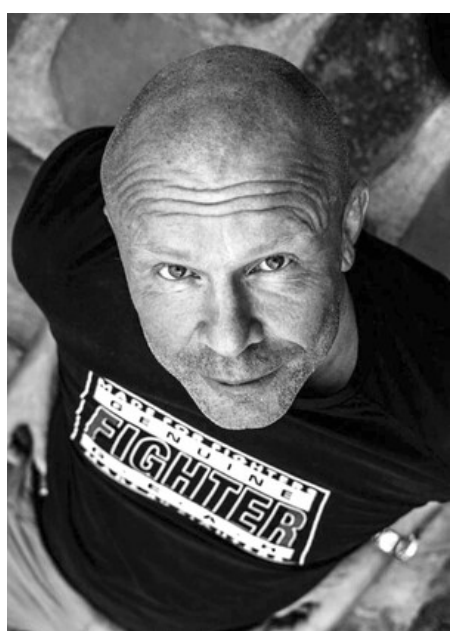

Sverre Eika døde brått og uventet av akutt sykdom 12. september, 55 år gammel.

Ingen har noen gang beskyldt Sverre for å være svigermors drøm. Tvert imot var han en skikkelig rabagast som prøvde det meste og utfordret grenser. Men nettopp det at han hadde levd et «rocka» liv, var det som førte ham inn i den unike rollen han etter hvert skulle få som «de narkomanes lege».

Han brukte mesteparten av sitt yrkesaktive liv til å ta seg av rusbrukere, blant annet på 24 sju (Kirkens Bymisjon). Med empati og rettferdighetssans hjalp han mange av de aller dårligste, de som falt utenfor alle hjelpetilbud og ordninger. Han erfarte at moralisme og stivbente regler stod i veien for å hjelpe tunge brukere bort fra gaten og til et verdig liv. Men hans forskrivning av narkotiske stoffer førte også til konflikt med noen av «ekspertene» på fagfeltet. Sverre var ikke redd for å utfordre retningslinjene, og flere ganger ble det reist tilsynssak mot ham, men han gikk fri hver gang.

Sverre engasjerte seg i den offentlige debatt om rusmiddelomsorgen. For sitt engasjement fikk han osloprisen Årets ildsjel i 2015 og Brukervennprisen i 2016. Han har vært med i flere TV-programmer, blant annet «Petter uteligger» og «Norge bak fasaden».

Sverre var jordnær og pragmatisk. Han hadde en egen evne til å forstå og finne en behandling som pasienten var i stand til å gjennomføre. Derfor kunne han også vise til gode resultater. Han hadde et stort og ubyråkratisk hjerte og var uvanlig kunnskapsrik. Hele felleskatalogen skulle tas i bruk, ikke bare noen få forhåndsgodkjente preparater. 
Ina Roll Spinnangr i Foreningen Tryggere Ruspolitikk skrev i en kronikk om ham kort tid etter hans død: «Da jeg traff Sverre Eika første gang, trodde jeg knapt mine egne øyne. Med glattbarbert hode, militærbukse, knyttnevehilsen og T-skjorte fra kampsportmerket Fighter, fremstod han mer som en soldat enn en lege. Det skulle vise seg at han på mange måter var begge deler. For der andre leger ville ha gitt opp i møte med systemet, gikk Sverre i krigen for alle som trengte hjelp. Og når systemet nektet å hjelpe, hjalp han dem selv.»

Til tross for sitt barske utseende var han en genuint vennlig mann. Som fanebærer for de mest sårbare og foraktede i samfunnet har han satt fart i arbeidet for å fornye retningslinjene og sørge for at rusavhengige blir møtt med forståelse, respekt og virksom behandling i stedet for avvisning, straff og fordømmelse.

Sverre etterlater seg et stort savn både hos familie, kolleger og pasienter.

Publisert: 8. november 2021. Tidsskr Nor Legeforen. DOI: 10.4045/tidsskr.21.0705

(C) Tidsskrift for Den norske legeforening 2023. Lastet ned fra tidsskriftet.no 26. april 2023. 